\title{
GASTROPROTECTIVE ACTIVITY OF SESAME (SESAMUM INDICUM) SEEDS EXTRACT IN ALENDRONATE-INDUCED GASTRIC ULCER IN RATS
}

\author{
SHUBANGEE MISHRA ${ }^{1}$, BALAJI $0^{2}$, VANISHREE RAO ${ }^{2}$, SHALINI ADIGA ${ }^{3 *}$ \\ Department of Pharmacology, Kasturba Medical College, Manipal Academy of Higher Education, Manipal, Karnataka, India. \\ Email: Shalini@manipal.edu
}

Received: 01 August 2019, Revised and Accepted: 27 August 2019

\begin{abstract}
Objectives: Bisphosphonates are known to cause gastritis and only few studies have evaluated the use of plant extracts in the treatment of bisphosphonate induced peptic ulcers. In the present study, we examined the effect of sesame seed extract in the alendronate-induced gastric ulcer in adult Wistar rats.

Methods: Thirty adult Wistar rats (180-250 g) of both sexes, divided into five groups (n=6) were used: Group 1 (vehicle control) - $0.9 \%$ saline, Group 2 (ulcer control) - alendronate $60 \mathrm{mg} / \mathrm{kg}$, Group 3 (standard) - alendronate $60 \mathrm{mg} / \mathrm{kg}+$ pantoprazole $30 \mathrm{mg} / \mathrm{kg} / \mathrm{day}$, Group 4 (test groups) - alendronate $60 \mathrm{mg} / \mathrm{kg}+$ sesame $0.5 \mathrm{mg} / \mathrm{kg}$, and Group 5 (test groups) - alendronate $60 \mathrm{mg} / \mathrm{kg}+$ sesame $1 \mathrm{mg} / \mathrm{kg}$. All drugs were given orally once daily for 7 days except for alendronate given only on day 1. On day 8, rats were sacrificed, and stomach tissues were analyzed macroscopically for ulcers. Estimation of gastric $\mathrm{pH}$, acidity, and volume was done along with mucin content measurement. One-way ANOVA followed by Tukey's post hoc test was used for statistical analysis with $\mathrm{p}<0.05$ taken as significant.
\end{abstract}

Results: Our study found that sesame extract given therapeutically at doses of 0.5 and $1 \mathrm{mg} / \mathrm{kg}$ showed comparable results with that of pantoprazole $30 \mathrm{mg} / \mathrm{kg}$. Both the doses of sesame, 0.5 and $1 \mathrm{mg} / \mathrm{kg}$ showed similar gastroprotective activity against alendronate-induced gastric ulcers in Wistar rats.

Conclusion: The findings of this study clearly demonstrated the protective effects of Sesame against alendronate-induced gastric ulceration.

Keywords: Gastroprotection, Sesame, Alendronate, Gastric ulcers.

(C) 2019 The Authors. Published by Innovare Academic Sciences Pvt Ltd. This is an open access article under the CC BY license (http://creativecommons. org/licenses/by/4. 0/) DOI: http://dx.doi.org/10.22159/ajpcr.2019.v12i10.35203

\section{INTRODUCTION}

Peptic ulcer disease is widespread globally and is said to be the most common gastrointestinal tract disorder in clinical practice. A survey revealed that $1.84 \%$ of population in the United States, $2.7 \%$ in Australia, and about $1.8 \%$ in Canada, and Great Britain and Egypt suffer from this disease [1]. Helicobacter pylori, nonsteroidal antiinflammatory drugs (NSAIDs), emotional stress, alcohol abuse, and smoking are the principal etiological factors associated with peptic ulcer [2].

Bisphosphonates are the most commonly prescribed drugs for the treatment of various bones diseases such as Paget's disease, osteolytic bone metastases, and osteoporosis. Studies revealed that oral administration of bisphosphonates, such as alendronate, can cause gastrointestinal adverse effects ranging from mild acid reflux, nausea, vomiting, and diarrhea to serious complications such as gastric erosions and even gastric ulcers [3-7].

According to literature research, rat models have confirmed the ability of alendronate to cause damage to the gastric mucosa and to exacerbate NSAID-induced gastric injury [8]. The exact mechanisms have been studied on since years, some of them being impairment in the gastric mucosal antioxidant mechanism, production of free radicals, and local irritation of the mucosa [9-12].

The sesame oil lignan sesamol (3,4-methylenedioxyphenol) is said to have potent antioxidative properties [13]. However, whether sesamol attenuates alendronate-induced gastric mucosal injury through this potent antioxidative effect has never been investigated. Therefore, the aim of our study is to find out the protective effect of sesame extract against gastric mucosal damage induced by the alendronate in Wistar albino rats.

\section{METHODS}

The study commenced after approval by the Institutional Animal Ethics Committee (IAEC/KMC/13/2016).

\section{Chemicals/drugs/instruments}

Pantoprazole, alendronate, ketamine, sesame extract, orcinol, phenolphthalein, Topfer's reagent, sulfuric acid, surgical kit, and suture material were used.

\section{Plant preparation and extraction}

The seeds were purchased from the local market and its authenticity was confirmed. The seeds were made into fine particles using electrical grinder to increase the surface contact with solvent in the extraction process. The powder obtained was bagged into thimble by cellulose, which was then placed in the Soxhlet instrument for extraction. Extraction solvent (ethanol) $90 \%$ was boiled in the round bottom flask at $40^{\circ} \mathrm{C}$ for a period of $24 \mathrm{~h}$, then essence was subjected to evaporation in a water bath to take out ethanol. The obtained yield was measured $(10 \%)$ and was preserved in desiccator till further use at room temperature.

\section{Animals}

Male/female albino rats of Wistar stain weighing 180-250 g and 1012 weeks were used for the study. The animals were housed under standard condition, $12: 12$ light-dark cycle, $50 \%$ humidity, and $28^{\circ} \mathrm{C}$ temperature and provided with standard food granules and water $a d$ libitum. 
Experimental design

Rats were divided into five groups of six rats each. Grouping is as follows:

- Group I - Normal, only vehicle $0.9 \%$ saline

- Group II - Control, alendronate $60 \mathrm{mg} / \mathrm{kg}$

- Group III - Alendronate $60 \mathrm{mg} / \mathrm{kg}$ (once only day 1) + pantoprazole $30 \mathrm{mg} / \mathrm{kg} /$ day (7 days)

- Group IV - Alendronate $60 \mathrm{mg} / \mathrm{kg}$ (once only day 1 ) + sesame $0.5 \mathrm{mg} / \mathrm{kg}$ (7 days)

- Group V-Alendronate $60 \mathrm{mg} / \mathrm{kg}$ (once only day 1 ) + sesame $1 \mathrm{mg} / \mathrm{kg}$ (7 days).

All the drugs/vehicles were given orally through gavage and dose of the drugs were selected based on previous research studies [14-16]. For $18 \mathrm{~h}$ before the experiment, the rats were given no food but allowed free access to tap water. The animals fasted for $18 \mathrm{~h}$ were given alendronate $(60 \mathrm{mg} / \mathrm{kg})$ orally through gavage on the $1^{\text {st }}$ day $1 \mathrm{~h}$ after the administration of test drugs. Then, rats were fed normally. Sesame and Pantoprazole were given $1 \mathrm{~h}$ before alendronate administration on the $1^{\text {st }}$ day and once daily for 6 days thereafter. On the last day, the animals were sacrificed by cervical dislocation, abdomen dissected, and then stomach was excised, opened along the greater curvature for the assessment of gastric damage.

\section{Measurement of parameters}

Ulcer size, ulcer number, and ulcer index

The stomach was dissected along the greater curvature and pinned on a board and using magnifying hand lens, tracing was done on the transparent paper and the paper onto graph sheets. The size of ulcers and the ulcer index were calculated using the following formula, ulcer index $=$ ulcer size $\times$ ulcer number [17]

\section{Determination of mucin content}

Orcinol (1.6\%) and sulfuric acid (60\%) were added to gastric juice, vortexed and boiled for $10 \mathrm{~min}$. Mixtures are cooled in ice cooled water to stop reaction and absorbance was studied at $425 \mathrm{~nm}$ [18].

\section{Measurement of volume of gastric juice}

The animals were sacrificed and gastric juice from the stomach was drained into a centrifuge tube and centrifuged at $3000 \mathrm{rpm}$ for $10 \mathrm{~min}$ and the final sample was decanted and analyzed for the volume of gastric juice [18].

\section{Measurement of $\mathrm{pH}$ of gastric juice}

$\mathrm{pH}$ of the centrifuged sample of gastric juice is measured using a digital pH Meyer, type DPH-100 (Dalal instruments).

\section{Measurement of free and total acidity}

The free and total acidity was measured by titrating $0.1 \mathrm{ml}$ of gastric juice with $0.01 \mathrm{~N} \mathrm{NaOH}$ using Topfer's reagent and phenolphthalein as indicators. Orange-yellow endpoint with Topfer's reagent for the free acid content and the pink endpoint with phenolphthalein for total acid content were noted, and acidity was calculated [19].

\section{Statistical analysis}

The data were anonymized and analyzed using one-way ANOVA in SPSS version 2.0 software. The level of statistical significance for any measure was set at $\mathrm{p}<0.05$ at a confidence interval of $95 \%$. The data expressed are in mean \pm standard error mean.

\section{RESULTS}

Effect on ulcer size, ulcer number, and ulcer index

The morphological pictures of stomach ulcer observed among all five groups are shown in Fig 1. Ulcers were observed in both ulcer and standard control group (pantoprazole), but vehicle control and sesame treatment groups did not have any ulcers. The results are tabulated in Table 1. All the groups showed a significant decrease in ulcer formation when compared with the entire ulcer control group. Both the doses of sesame did not show any significant difference in ulcer measurement when compared with normal control and pantoprazole treated group.

\section{Effect on mucin content}

Results are shown in Table 2. All the groups showed a significant increase in mucin content when compared with the entire ulcer control group.

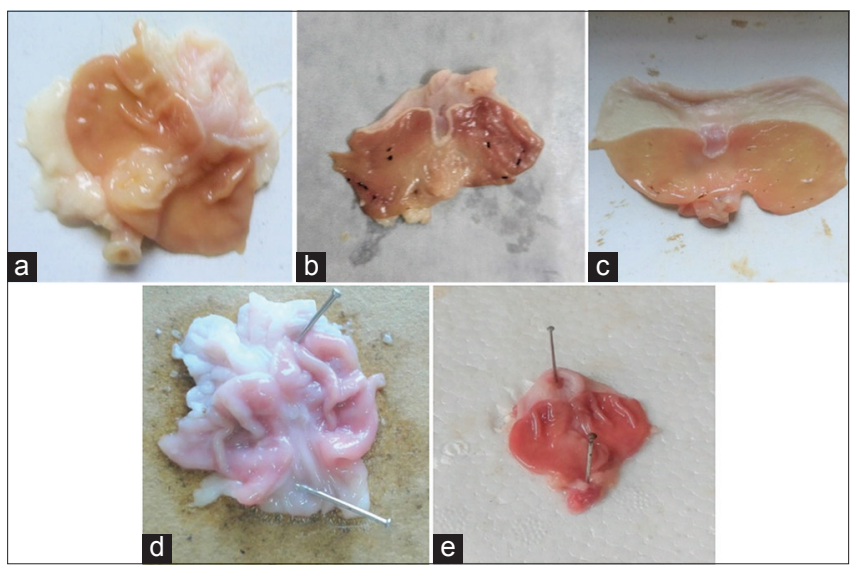

Fig. 1: Gross ulcers in rat stomach. (a): Normal vehicle control, (b): Ulcer control, (c): Standard control (pantoprazole), (d): Sesame $0.5 \mathrm{mg} / \mathrm{kg}$, (e): Sesame $1 \mathrm{mg} / \mathrm{kg}$

Table 1: Ulcer measurement parameters

\begin{tabular}{|c|c|c|c|}
\hline Group $n=6$ & $\begin{array}{l}\text { Mean ulcer } \\
\text { size }(\mathrm{mm}) \\
\text { Mean } \pm \text { SEM }\end{array}$ & $\begin{array}{l}\text { Mean ulcer } \\
\text { number } \\
\text { Mean } \pm \text { SEM }\end{array}$ & $\begin{array}{l}\text { Mean ulcer } \\
\text { index } \\
\text { Mean } \pm \text { SEM }\end{array}$ \\
\hline $\begin{array}{l}\text { Group I } \\
\text { (vehicle normal control) }\end{array}$ & $0 *$ & $0 *$ & $0 *$ \\
\hline $\begin{array}{l}\text { Group II } \\
\text { (ulcer control) }\end{array}$ & $4.48 \pm 0.32$ & $6.33 \pm 0.66$ & $29.2 \pm 4.57$ \\
\hline $\begin{array}{l}\text { Group III } \\
\text { (pantoprazole) }\end{array}$ & $0.45 \pm 0.30 *$ & $1.3 \pm 1.14^{*}$ & $2.20 \pm 2.01^{*}$ \\
\hline $\begin{array}{l}\text { Group IV } \\
\text { (sesame } 0.5 \mathrm{mg} / \mathrm{kg} \text { ) }\end{array}$ & $0^{*}$ & $0^{*}$ & $0^{*}$ \\
\hline $\begin{array}{l}\text { Group V } \\
\text { (sesame } 1 \mathrm{mg} / \mathrm{kg} \text { ) }\end{array}$ & $0^{*}$ & $0^{*}$ & $0^{*}$ \\
\hline
\end{tabular}

${ }^{*} \mathrm{p}<0.001$ : All groups versus Group 2. Values were expressed as mean \pm SEM, one-way ANOVA was used to compare the means between the groups followed by Tukey's post hoc analysis with $\mathrm{P}<0.05$ as statistically significant. SEM: Standard error of mean

Table 2: Gastric fluid analysis

\begin{tabular}{llll}
\hline Groups n=6 & $\begin{array}{l}\text { pH } \\
(\text { Mean } \pm \text { SEM) }\end{array}$ & $\begin{array}{l}\text { Volume } \\
(\mathbf{m l} / \mathbf{1 0 0} \text { g) } \\
(\text { Mean } \pm \text { SEM) }\end{array}$ & $\begin{array}{l}\text { Mucin } \\
\text { content } \\
\text { (Mean } \pm \text { SEM) }\end{array}$ \\
\hline $\begin{array}{l}\text { Group I (vehicle } \\
\text { normal control) } \\
\text { Group II }\end{array}$ & $4.94 \pm 0.02^{\$}$ & $2.51 \pm 0.08^{\$}$ & $367.1 \pm 2.1^{\$}$ \\
$\begin{array}{l}\text { (ulcer control) } \\
\begin{array}{l}\text { Group III } \\
\text { (pantoprazole) }\end{array}\end{array}$ & $2.5 \pm 0.07$ & $7.39 \pm 0.06$ & $229.5 \pm 3.2$ \\
$\begin{array}{l}\text { Group IV } \\
\text { (sesame } 0.5 \mathrm{mg} / \mathrm{kg})\end{array}$ & $4.67 \pm 0.07^{\$ *}$ & $3.91 \pm 0.035^{\$ *}$ & $350.5 \pm 5.91^{\$ *}$ \\
$\begin{array}{l}\text { Group V } \\
\text { (sesame } 1 \mathrm{mg} / \mathrm{kg})\end{array}$ & $4.31 \pm 0.04^{\$ * \#}$ & $4.27 \pm 0.30^{\$ *}$ & $346.3 \pm 3.74^{\$ *}$ \\
\hline
\end{tabular}

${ }^{\$} \mathrm{p}<0.001$ : All groups versus Group 2; ${ }^{\mathrm{p}}<0.001$ : Group 3, 4, 5, versus 1; ${ }^{\#} \mathrm{p}<0.001$ : Group 5 versus Group 3. Values were expressed as mean \pm SEM one-way ANOVA was used to compare the means between the groups followed by Tukey's post hoc analysis with $\mathrm{P}<0.05$ as statistically significant. SEM: Standard error of mean 
Sesame treated groups did not show any difference in mucin content when compared with pantoprazole group. All groups showed significant decrease in mucin content when compared with normal control group. There was no significant difference between Groups 4 and Group 5 (Fig. 2).

\section{Effect on volume of gastric juice}

Results are shown in Table 2 . All groups showed a significant decrease in gastric juice volume when compared with ulcer control group. Sesame treatment groups did not show any difference in gastric juice volume when compared with pantoprazole treated group. All groups showed significant increase in gastric volume when compared with normal control group. There was no significant difference between the two doses of sesame (Fig. 3).

\section{Effect on $\mathbf{p H}$ of gastric juice}

Results are shown in Table 3. All groups showed significant higher $\mathrm{pH}$ when compared with all the ulcer control groups. Group 5 with gastric $\mathrm{pH}$ of $4.31 \pm 0.04$ showed significant reduction of $\mathrm{pH}$ when compared with Group 3. Group 4 did not show any significant difference in $\mathrm{pH}$ when compared with Group 3. All groups showed significant higher $\mathrm{pH}$ when compared with Group 1. There was no significant difference between Group 4 and Group 5 (Fig. 3).

\section{Effect on free acidity}

Results are shown in Table 2. All groups showed significant higher acidity levels when compared with the ulcer control group. Group 4 and Group 5 showed reduction in free acidity when compared with Group 3. All groups showed significant increase in free acidity when compared with Group 1. There was no significant difference between Groups 4 and Group 5 (Fig. 4).

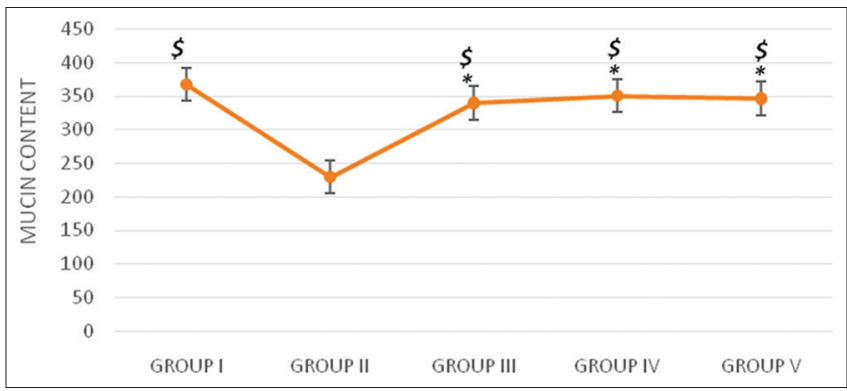

Fig. 2: Mucin content estimation. ${ }^{s} \mathbf{p}<0.001$ : All groups versus Group 2; ${ }^{*} \mathbf{p}<0.001$ : Group 3, 4, 5, versus 1. Values were expressed as mean \pm standard error of mean, one-way ANOVA was used to compare the means between the groups followed by Tukey's post hoc analysis with $\mathrm{p}<0.05$ as statistically significant

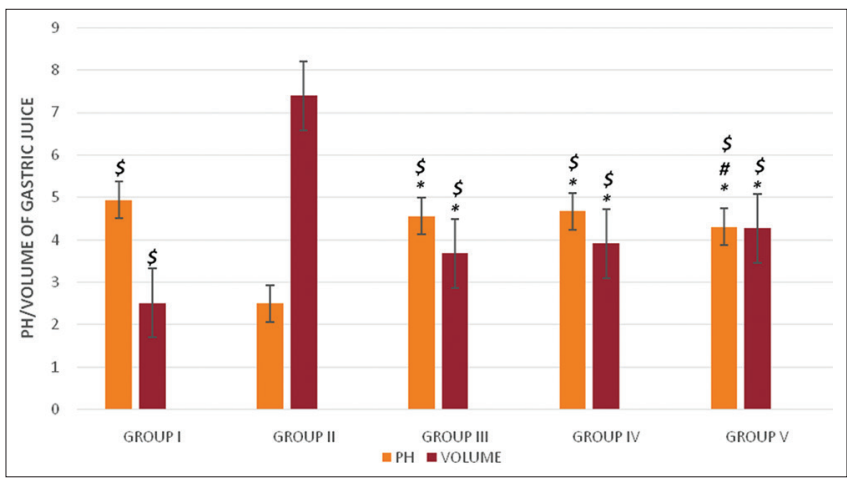

Fig. 3: Gastric fluid analysis. ${ }^{\$} \mathbf{p}<0.001$ : All groups versus Group 2; ${ }^{*} \mathbf{p}<0.001$ : Group 3, 4, 5 versus 1; ${ }^{*} \mathbf{p}<0.001$ : Group 5 versus Group 3. Values were expressed as mean \pm standard error of mean, one-way ANOVA was used to compare the means between the groups followed by Tukey's post hoc analysis with $\mathrm{p}<0.05$ as statistically significant
Effect on total acidity

Results are shown in Table 3. All groups showed a significant increase when compared with all the other groups. Groups 4 and 5 did not show any difference when compared with Group 3. All groups showed significantly higher total acidity when compared with Group 1 . There was no significant difference between Group 4 and Group 5 (Fig. 4).

\section{DISCUSSION}

The results of the present study revealed that alendronate produced gastric injury as evidenced by the changes in the gastric mucosa, mucin content, gastric $\mathrm{pH}$, volume, and free and total acidity. This was in accordance with previous studies done using alendronate in peptic ulcer rat models. The mechanisms behind how alendronate induces gastric mucosal injury/ulcers are still unclear though various theories have been postulated. One of them being attenuation of $\mathrm{NO} / \mathrm{cGMP} / \mathrm{K}_{\text {ATP }}$ signaling pathway and modulating nitric oxide synthase expression, thus reducing NO generation which causes impairment in the gastric mucosal antioxidant mechanism [9].

Alendronate-induced neutrophil accumulation and subepithelial edema in the gastric mucosa have also been shown to play major roles in the development of ulcers [12]. Elliott et al. (1998) studied the effect of ALD in rats and rabbits and observed that the damaging effects of the drug were not attributable to changes in gastric acid secretion, blood flow or PG synthesis; they concluded that the damaging effects of ALD on the stomach were due to a topical irritant effect [20]. Peter et al.

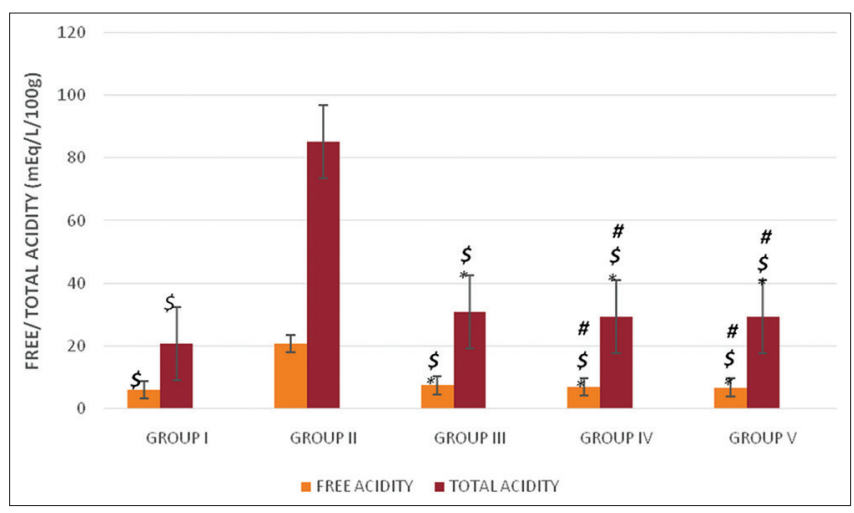

Fig. 4: Gastric acidity measurements. ${ }^{\$} \mathbf{p}<0.001$ : All groups versus Group 2; *p<0.001: Group 3, 4, 5, versus 1; ${ }^{\#} \mathbf{p}<0.001$ : Group 4, 5 versus Group 3. Values were expressed as mean \pm standard error of mean, one-way ANOVA was used to compare the means between the groups followed by Tukey's post hoc analysis with $\mathbf{p}<0.05$ as statistically significant

Table 3: Gastric fluid acidity measurement

\begin{tabular}{|c|c|c|}
\hline Groups $n=6$ & $\begin{array}{l}\text { Free acidity } \\
(\mathrm{mEq} / \mathrm{L} / 100 \mathrm{~g})\end{array}$ & $\begin{array}{l}\text { Total acidity } \\
(\mathrm{mEq} / \mathrm{L} / 100 \mathrm{~g})\end{array}$ \\
\hline $\begin{array}{l}\text { Group I } \\
\text { (vehicle normal control) }\end{array}$ & $5.9 \pm 0.03^{\$}$ & $20.6 \pm 0.63^{\$}$ \\
\hline $\begin{array}{l}\text { Group II } \\
\text { (ulcer control) }\end{array}$ & $20.7 \pm 0.17$ & $85.3 \pm 0.50$ \\
\hline $\begin{array}{l}\text { Group III } \\
\text { (pantoprazole) }\end{array}$ & $7.3 \pm 0.12^{\$ *}$ & $30.8 \pm 0.39^{\$ *}$ \\
\hline $\begin{array}{l}\text { Group IV } \\
\text { (sesame } 0.5 \mathrm{mg} / \mathrm{kg} \text { ) }\end{array}$ & $6.7 \pm 0.03^{\$ * \#}$ & $29.29 \pm 0.41^{\text {s* }}$ \\
\hline $\begin{array}{l}\text { Group V } \\
\text { (sesame } 1 \text { mg/kg) }\end{array}$ & $6.6 \pm 0.05^{\$ * \#}$ & $29.36 . \pm 0.39^{\$ *}$ \\
\hline
\end{tabular}

${ }^{\$} \mathrm{p}<0.001$ : All groups versus Group 2; ${ }^{*} \mathrm{p}<0.001$ : Group 3, 4, 5 versus 1; $\# \mathrm{p}<0.001$ : Group 4, 5, versus Group 3. Values were expressed as mean \pm SEM, one-way ANOVA was used to compare the means between the groups followed by Tukey's post hoc analysis with $\mathrm{P}<0.05$ as statistically significant. SEM: Standard error of mean 
(1998) showed that at $\mathrm{pH}<2$, ALD sodium is converted to its acid form, which is known to be more irritating than the sodium salt [21].

In this study, ALD was administered orally in fasted rats; it seems likely that the gastric damage is, due to the direct irritating effect of the drug in its acid form. Besides the animal models, clinically used doses of alendronate have been recognized to cause gastric mucosal damage and acute drug-induced ulcers [22]. A study by Chesnut et al. in osteoporotic female patients undergoing alendronate therapy showed that incidence of upper gastrointestinal adverse effect was the commonly observed one being more in the group receiving higher therapeutic doses of $40 \mathrm{mg} /$ day alendronate as compared to 5 and $10 \mathrm{mg} / \mathrm{kg}$ [4]

Sesame (Sesamum indicum) which belongs to family Pedaliaceae, has several industrial, nutraceutical, and pharmaceutical uses [7]. It is aid used as a solvent for intramuscular injections and has nutritive, demulcent, and emollient properties [23] and has also been used as a laxative. It contains compounds such as sesamin, sesaminol, gammatocopherol, cephalin, and lecithin. These compounds impart many of the pharmacological activities such as antioxidant, antibacterial, cardiotonic, antidiabetic, hypocholesterolemia, antitumor, antiulcer, anti-inflammatory, and analgesic properties to sesame [24]. Sesame is proven to possess antioxidant activity, blood pressure and serum lipidlowering property in experimental animals and humans [25].

In our study, sesame treatment showed a remarkable reversal of gastric mucosal damage induced by alendronate. The sesame offered gastric protection comparable to the standard drug pantoprazole $30 \mathrm{mg} / \mathrm{kg}$ with respect to ulcer formation and gastric juice parameters. Free acidity levels were significantly lower in sesame treated group when compared with pantoprazole treated group. The results seen in our study were similar to other studies in literature with respect to sesame in the treatment of peptic ulcer. Sesame was shown to protect against ethanol [16] and stress-induced [26] gastric ulcers in rats. Since the damaging effects of both ethanol and stress are known to be closely associated with the impairment of mucosal barrier mechanisms, which involves the generation of reactive oxygen species, it is possible that sesame, through its antioxidant effects, reinforces the mucosal barrier function.

\section{Limitation}

Histopathological analysis, assessment of pre- and post-treatment levels of inflammatory or oxidative stress markers could have been better supported our results; we find this as one of the limitations.

\section{CONCLUSION}

Therefore, the findings of the present study suggest that alendronate induces gastric damage by a local irritant effect, and sesame ameliorates this damage by its possible antioxidant property. Effect of sesame extract has been already done on NSAIDs-induced, ethanol-induced, and stress-induced gastric ulcer models but never on alendronate-induced gastric damage model. Hence, this model can prove to be helpful in demonstrating gastro-protective property of newer agents. Although sesamol showed significant gastric protection against alendronate in this pharmacological animal study, more clinically oriented studies are needed to assess its potential for clinical use.

\section{AUTHORS' CONTRIBUTIONS}

The authors would like to thank the Department of Pharmacology, KMC, Manipal, and also like to thank Dr. Balaji for the entire idea for the project as well as Vanishree Rao in Writing the article and doing the drafting of the results.

\section{CONFLICTS OF INTEREST}

Nil.

\section{REFERENCES}

1. Cai S, García Rodríguez LA, Massó-González EL, Hernández-Díaz S. Uncomplicated peptic ulcer in the UK: Trends from 1997 to 2005.
Aliment Pharmacol Ther 2009;30:1039-48.

2. Malfertheiner P, Chan FK, McColl KE. Peptic ulcer disease. Lancet 2009;374:1449-61.

3. Fleisch H. Bisphosphonates in Bone Disease: From the Laboratory to the Patient. New York: The Parthenon Group; 1997. p. 32-163.

4. Chesnut $\mathrm{CH}^{\text {rd }}$, McClung MR, Ensrud KE, Bell NH, Genant HK, Harris ST, et al. Alendronate treatment of the postmenopausal osteoporotic woman: Effect of multiple dosages on bone mass and bone remodeling. Am J Med 1995;99:144-52.

5. de Groen PC, Lubbe DF, Hirsch LJ, Daifotis A, Stephenson W, Freedholm D, et al. Esophagitis associated with the use of alendronate. N Engl J Med 1996;335:1016-21

6. Graham DY, Malaty HM. Alendronate gastric ulcers. Aliment Pharmacol Ther 1999;13:515-9.

7. Graham DY. What the gastroenterologist should know about the gastrointestinal safety profiles of bisphosphonates. Dig Dis Sci 2002; 47:1665-78.

8. Ohashi Y, Aihara E, Takasuka H, Takahashi K, Takeuchi K. Antral ulcers induced by alendronate, a nitrogen-containing biphophonate, in rat stomachs prophylactic effect of rebamipide. J Physiol Pharmacol 2009;60:85-93.

9. Silva RO, Lucetti LT, Wong DV, Aragão KS, Junior EM, Soares PM, et al. Alendronate induces gastric damage by reducing nitric oxide synthase expression and $\mathrm{NO} / \mathrm{cGMP} / \mathrm{K}(\mathrm{ATP})$ signaling pathway. Nitric Oxide 2014;40:22-30.

10. Shinohara T, Takahashi N, Kohno H, Yamanaka K, Ooie T, Wakisaka O, et al. Mitochondria are targets for geranylgeranylacetone-induced cardioprotection against ischemia-reperfusion in the rat heart. Am J Physiol Heart Circ Physiol 2007;293:H1892-9.

11. Nagano Y, Matsui H, Muramatsu M, Shimokawa O, Shibahara T, Yanaka A, et al. Rebamipide significantly inhibits indomethacininduced mitochondrial damage, lipid peroxidation, and apoptosis in gastric epithelial RGM-1 cells. Dig Dis Sci 2005;50 Suppl 1:S76-83.

12. Wallace JL, Dicay M, McKnight W, Bastaki S, Blank MA. N-bisphosphonates cause gastric epithelial injury independent of effects on the microcirculation. Aliment Pharmacol Ther 1999;13:1675-82.

13. Hsu DZ, Chen KT, Li YH, Chuang YC, Liu MY. Sesamol delays mortality and attenuates hepatic injury after cecal ligation and puncture in rats: Role of oxidative stress. Shock 2006;25:528-32.

14. Amagase K, Hayashi S, Nishikawa K, Aihara E, Takeuchi K. Impairment of gastric ulcer healing by alendronate, a nitrogencontaining bisphosphonate, in rats. Dig Dis Sci 2007;52:1879-89.

15. Lee HJ, Han YM, Kim EH, Kim YJ, Hahm KB. A possible involvement of nrf2-mediated heme oxygenase-1 up-regulation in protective effect of the proton pump inhibitor pantoprazole against indomethacininduced gastric damage in rats. BMC Gastroenterol 2012;12:143.

16. Hsu DZ, Chen YW, Chu PY, Periasamy S, Liu MY. Protective effect of 3,4-methylenedioxyphenol (sesamol) on stress-related mucosal disease in rats. Biomed Res Int 2013;2013:481827.

17. Rao CM, Ramesh KU, Bairy KL, Kulkarni OR. Zinc Complexes of NSAID's abolish Gastric ulceration propensity of parent durg. Indian Drugs 1990:28;64-7.

18. Khayyal MT, el-Ghazaly MA, Kenawy SA, Seif-el-Nasr M, Mahran LG, Kafafi YA, et al. Antiulcerogenic effect of some gastrointestinally acting plant extracts and their combination. Arzneimittelforschung 2001;51:545-53

19. Anoop A, Jegadeesan M. Biochemical studies on the anti-ulcerogenic potential of hemidesmus indicus R.Br. Var. Indicus. J Ethnopharmacol 2003;84:149-56

20. Elliott SN, McKnight W, Davies NM, MacNaughton WK, Wallace JL. Alendronate induces gastric injury and delays ulcer healing in rodents. Life Sci 1998;62:77-91.

21. Peter CP, Handt LK, Smith SM. Esophageal irritation due to alendronate sodium tablets: Possible mechanisms. Dig Dis Sci 1998;43:1998-2002.

22. Graham DY, Malaty HM, Goodgame R. Primary aminobisphosphonates: A new class of gastrotoxic drugs comparison of alendronate and aspirin. Am J Gastroenterol 1997;92:1322-5.

23. Morris JB. Food, Industrial, Nutraceutical, and Pharmaceutical Uses of Sesame Genetic Resources. Trends in New Crops and New Uses. Alexandria, VA: ASHS Press; 2002. p. 153-6.

24. Sirato-Yasumoto S, Katsuta M, Okuyama Y, Takahashi Y, Ide T. Effect of sesame seeds rich in sesamin and sesamolin on fatty acid oxidation in rat liver. J Agric Food Chem 2001;49:2647-51.

25. Anilkumar K, Pal A, Khanum F, Bawa A. Nutritional, medicinal and industrial uses of sesame (Sesamum indicum L.) seeds an overview. Agric Conspectus Sci 2010;75:159-68.

26. Hsu DZ, Chu PY, Liu MY. Effect of sesame oil on acidified ethanol-induced gastric mucosal injury in rats. JPEN J Parenter Enteral Nutr 2009;33:423-7. 